\title{
The Characteristics of Fast Speed Walking in Old Men from the Viewpoint of the Ground Reaction Forces
}

\author{
Kazuo MAIE ${ }^{1)}$, Tadatoshi YAMADA ${ }^{2)}$, Shiro KONDO ${ }^{1)}$ and \\ Hideyuki TANAKA ${ }^{1)}$ \\ 1) The Institute of Human Living Sciences, \\ Otsuma Women's University \\ 2) Bridgestone Corp., Sports Research Division
}

\begin{abstract}
Characteristics of the fast speed walking in old men, primarily from the viewpoint of the ground reaction forces, were investigated in comparison with those during the ordinary speed walking. As a result, the following were recognized as the characteristics of fast speed walking in old men; (1) the walking speed, step length, and brake impulse as well as acceleration impulse began to decrease pronouncedly from the age group in their $60 \mathrm{~s}$, (2) the walking of subjects in their $60 \mathrm{~s}$ and $70 \mathrm{~s}$ were hastened from the ordinary speed level with almost the same ratios as in the younger subjects, (3) increase of the step length during the fast speed walking, against those during the ordinary speed walking, was smaller in subjects in their 70s than in the younger, (4) increase of the brake impulse during the fast speed walking, against those during the ordinary speed walking, began to decrease from the age-group in their $60 \mathrm{~s}$, while (5) that of the acceleration impulse remained unchanged with age. The principal component analysis revealed that (6) the contents of the fast speed walking are almost identical in ages between $20 \mathrm{~s}$ and $50 \mathrm{~s}$, suggesting that they begin to change at one's $60 \mathrm{~s}$.
\end{abstract}

Key Words Fast speed walking, Step length, Ground reaction forces, Old men, Principal component analysis

\section{Introduction}

A number of studies have reported on the characteristics of walking in the elderly. For instance, MURRAY et al. (1969) summarized their previous studies (MURRAY et al., 1964, 1966a, 1966b, 1967) that the old men walked with shorter stride, broader step breadth, lower cadence, less swing-to-stance phase duration, and less movement of several body segments. They also reported that the walking in old men beyond 65 years old were widely different from that in the younger. YAMADA et al. (1988) reported, primarily from the viewpoint of the ground reaction forces, that the characteristics of ordinary speed walking in old men were as follows; 1) the impulses of brake and acceleration decreased in the age-groups of $60 \mathrm{~s}$ and $70 \mathrm{~s}, 2$ ) the transverse

Article No. 9209 Received August 25, 1992 
peak force (outward) and its impulse increased in $60 \mathrm{~s}$ and $70 \mathrm{~s}, 3)$ the $1 \mathrm{st}$ and 2 nd peaks of the vertical force decreased and its minimum force increased in 60s and 70s, 4) the step length and the walking speed decreased in 60s and 70s, and 5) from the principal component analysis, the contents of the 1st, 2nd, and 3rd principal components remained almost unchanged from 20 s to 40 s, but altered according to age-groups from $50 \mathrm{~s}$ to $70 \mathrm{~s}$, suggesting that the ordinary speed walking begins to change at one's $50 \mathrm{~s}$.

With respect to the walking at higher speeds, however, studies seems to be scarce for the elderly. The maximum speed walking is regarded as a useful measure of physical fitness (ITO et al., 1989), but it is not always suitable for the elderly. We thought that the fast speed walking could be one of the indices of physical fitness, especially for the elderly, in place of the maximum speed walking. Besides, information on the biomechanical features of the fast speed walking would be useful for the shoe construction.

The purpose of this study is to clarify, primarily from the viewpoint of the ground reaction forces, the characteristics of fast speed walking in old men, in comparison with the ordinary speed walking. The data of ordinary speed walking are just the same as those used in our previous paper (YAMADA et al., 1988).

\section{Subjects and Methods}

The subjects were 66 male Japanese living around Tokyo, aged from 23 to 78 years, who were the same subjects examined in our previous paper (YAMADA et al., 1988). They were divided into six age groups; 20s, 30s, 40s, 50s, 60s, and $70 \mathrm{~s}$. The subjects in their $70 \mathrm{~s}$ were the members of a gate-ball sports club. The physical characteristics of the subjects are listed in Table 1.

The subjects were asked to walk barefoot at their own fast speeds for several times, on the level indoor track of ten meters long. The instruction given to the subjects was only "Please walk naturally at your fast speed". The characteristics of walking, as have been noticed frequently, depend on the walking speed (KIMURA, 1985). But we did not control their walking speed by showing the speed or cadence indicator, in order to avoid the awkwardness of gait caused by the speed or cadence control. The walking speed was measured by analyzing video images, and the step length was measured from the foot prints marked by white powder.

A force platform (Kistler Co.) of $60 \mathrm{~cm}$ long and $40 \mathrm{~cm}$ wide was set in the middle of the track. The three dimensional ground reaction forces, sagittal (Fs), transverse (Ft), and vertical (Fv) were led to the microcomputer and sampled at $100 \mathrm{~Hz}$. The force parameters used in this study are shown in Fig. 1. To diminish the effect of the absolute body weight, each parameter was

Table 1. Physical characteristics of the subjects

\begin{tabular}{lccccccccc}
\hline \multirow{2}{*}{$\begin{array}{c}\text { Age } \\
\text { group }\end{array}$} & \multirow{2}{*}{$\begin{array}{c}\text { Subject's } \\
\text { number }\end{array}$} & \multicolumn{3}{c}{$\begin{array}{c}\text { Age (yrs.) } \\
\text { Mean }\end{array}$} & S.D. & \multicolumn{2}{c}{$\begin{array}{c}\text { Stature }(\mathrm{cm}) \\
\text { Mean }\end{array}$} & S.D. & \multicolumn{2}{c}{ Foot lgth. (cm) } & \multicolumn{2}{c}{$\begin{array}{c}\text { Grip strgth. (kg) } \\
\text { Mean }\end{array}$} & S.D. & Mean & S.D. \\
\hline $70 \mathrm{~s}$ & 11 & 74.3 & 2.28 & 157.8 & 5.76 & 23.49 & 0.66 & 34.8 & 5.30 \\
$60 \mathrm{~s}$ & 10 & 67.3 & 1.57 & 162.8 & 4.75 & 24.37 & 1.06 & 37.5 & 6.10 \\
$50 \mathrm{~s}$ & 10 & 51.8 & 1.40 & 167.0 & 4.79 & 25.17 & 0.84 & 49.0 & 6.84 \\
$40 \mathrm{~s}$ & 10 & 43.2 & 2.30 & 164.7 & 5.38 & 24.41 & 0.79 & 46.0 & 6.98 \\
$30 \mathrm{~s}$ & 13 & 34.2 & 2.94 & 169.2 & 6.13 & 24.78 & 0.86 & 48.3 & 5.43 \\
$20 \mathrm{~s}$ & 12 & 26.2 & 1.85 & 170.8 & 6.47 & 25.12 & 0.89 & 50.0 & 7.58 \\
\hline
\end{tabular}




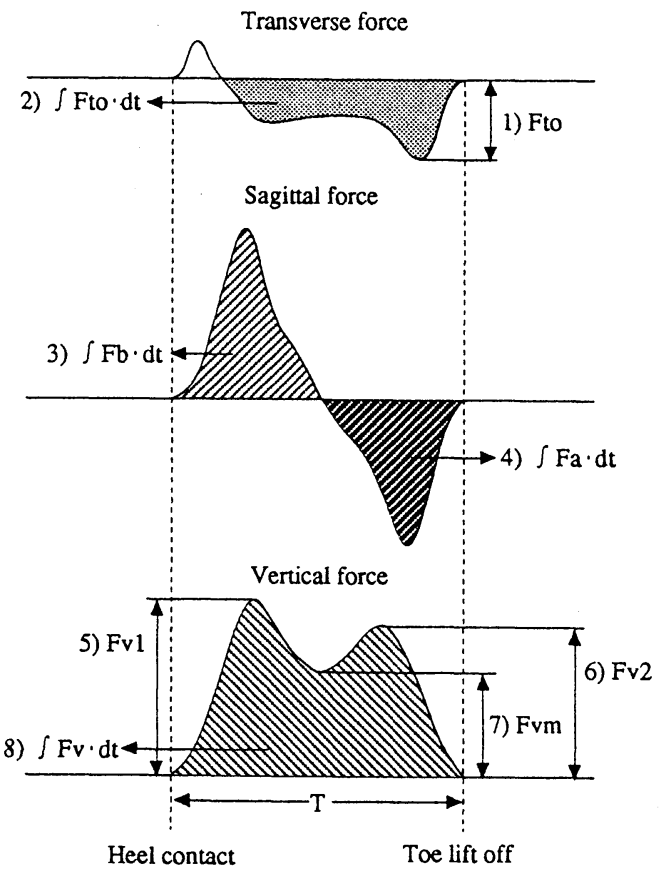

Fig. 1. The ground reaction force parameters used in the analysis: 1) Fto and 2) $\int$ Fto dt in the transverse force mean the outwards peak value and the outwards impulse, respectively; 3) $\int \mathrm{Fb} \cdot \mathrm{dt}$ and 4) $\int \mathrm{Fa} \cdot \mathrm{dt}$ in the sagittal force mean the impulses of brake and acceleration, respectively; 5) Fv1, 6) Fvm, and 7) Fv2 in the vertical force mean the first peak value, the minimum value, and the second peak value, respectively; 8 ) $\int F v \cdot d t$ in the vertical force means the vertical impulse. The eight items were normalized by the body weight (W) or the product (WT) of the W multiplied by the stance phase duration $(\mathrm{T})$.

normalized by the body weight (W) or the product of the body weight multiplied by the stance phase duration (WT). The ground reaction forces of the right foot in the most natural trial were used as the data.

The Principal Component Analysis (PCA) was applied to the ground reaction force items. In the preliminary analysis, the items with low contribution coefficients, such as the maximum Ft at heel contact, and one of two items showing high linear correlation coefficients, such as the braking component of the sagittal force $(\mathrm{Fb})$ and its impulse, were omitted. Finally, the following eight items of the ground reaction forces were chosen for the PCA; 1) the normalized outward peak force of Ft at toe kick-off; Fto/W, 2) the normalized outward impulse of $\mathrm{Ft}$; $\int \mathrm{Fto} \cdot \mathrm{dt} /$ WT, 3) the normalized impulse of Fb; $\int \mathrm{Fb} \bullet \mathrm{dt} /$ WT, 4) the normalized impulse of the accelerating component of the sagittal force $(\mathrm{Fa})$; $\left.\int \mathrm{Fa} \cdot \mathrm{dt} / \mathrm{WT}, 5\right)$ the normalized 1st peak force of Fv; Fv1/W, 6) the normalized 2nd peak force of Fv; Fv2/W, 7) the normalized minimum force of Fv; Fvm/W, and 8) the normalized impulse of Fv; $\int$ Fv・dt/WT. In addition to those items, the step length, walking speed, and grip strength as indices of physical fitness were included for the PCA. The PCA with varimax rotation was performed for each age group as well as for the whole subjects.

\section{Results and Discussion}

The mean and standard deviation of the walking speed, step length, step length relative to the stature, and eight items of the ground reaction forces during the fast speed walking are listed for each age group in Table 2, in comparison with those during the ordinary speed walking.

Fig. 2 illustrates the results for the walking speed, which decrease like a stair or sawtooth pattern at one's $40 \mathrm{~s}$ and $60 \mathrm{~s}$, both for ordinary and fast speed walking. The mean walking speeds of fast speed walking in 60s and 70s were lower than those of the ordinary speed walking in 20 s and 30s. MURRAY et al. (1969) reported a similar trend for the mean walking speed; it decreased like a stair pattern at the age group of 67-73, during both ordinary and fast speed walking. However, their mean speeds of the fast speed walking in three age groups over $67-73$ were not lower than those during the ordinary speed walking in the age group of 20-25.

Fig. 3 compares the step length between the 


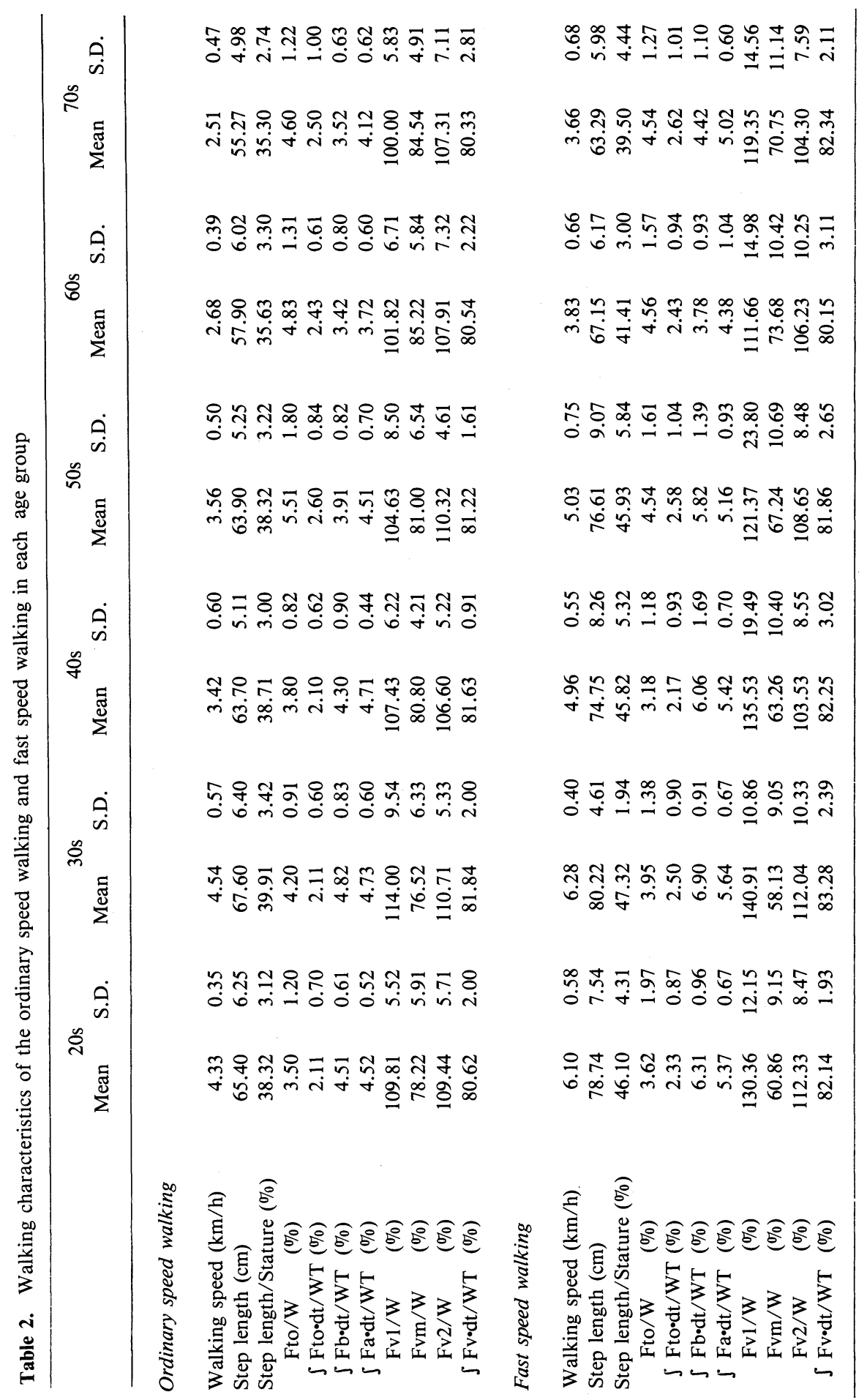




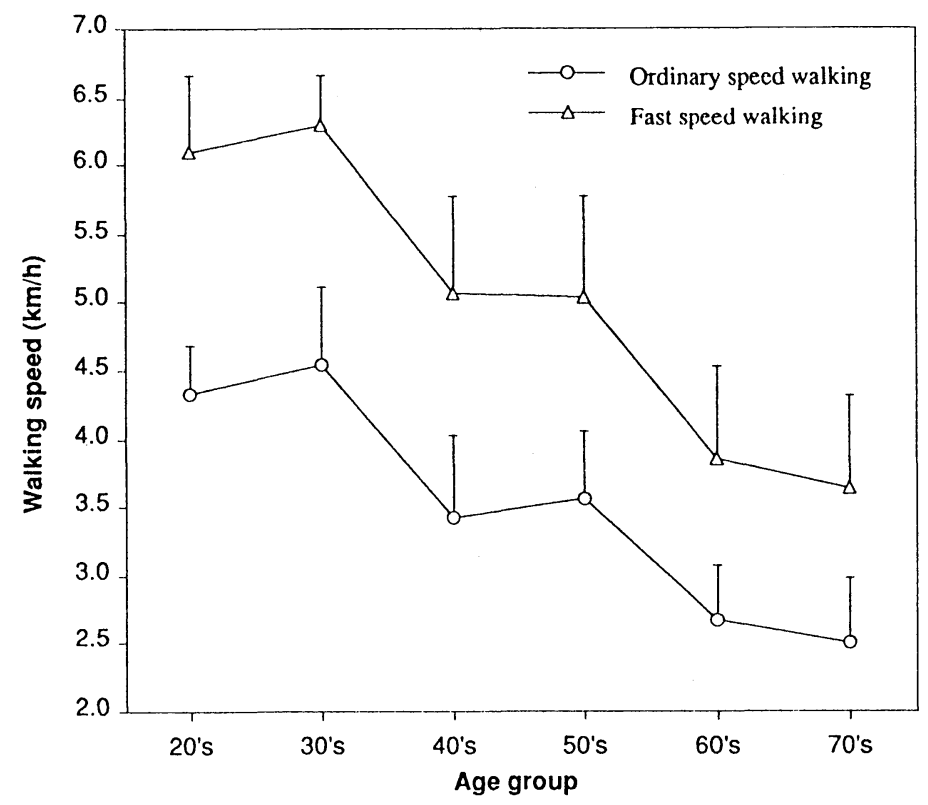

Fig. 2. The mean walking speed in each age group. Vertical bars indicate $+1 \mathrm{SD}$.

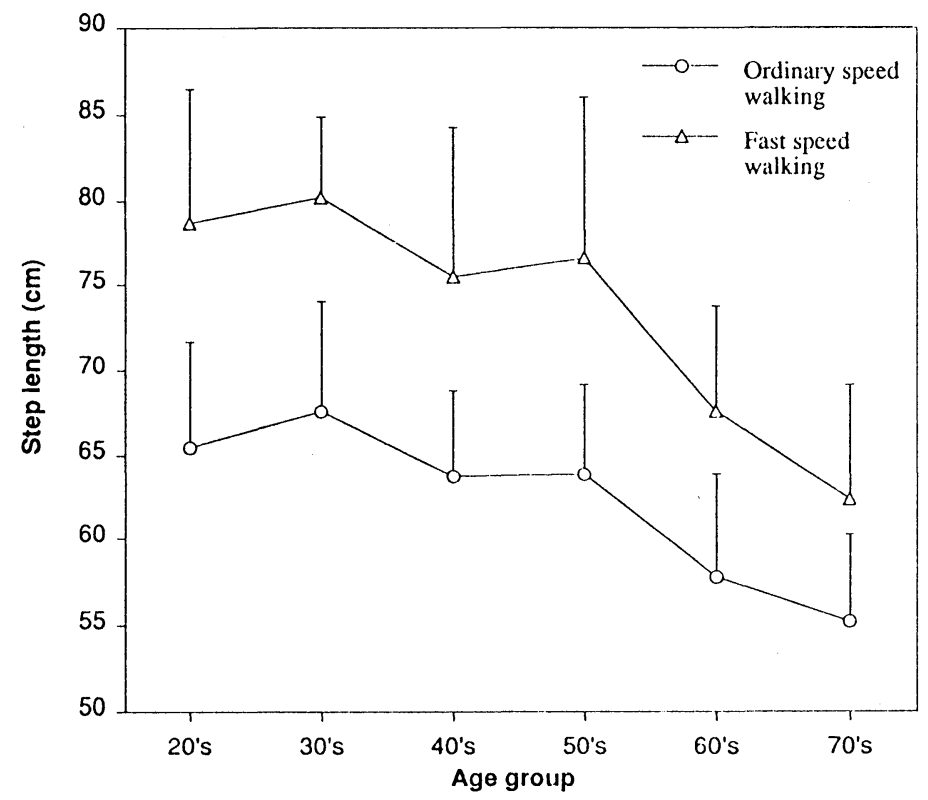

Fig. 3. The mean step length in each age group. Vertical bars indicate $+1 \mathrm{SD}$. 


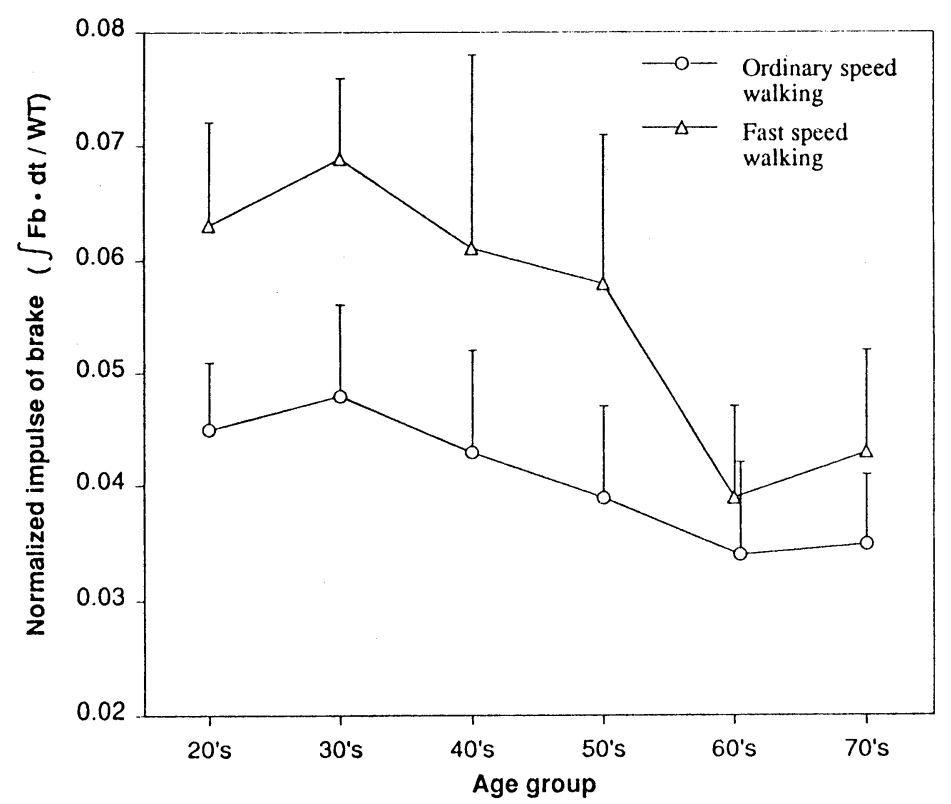

Fig. 4. The mean normalized impulse of brake in each age group. Vertical bars indicate $+1 \mathrm{SD}$.

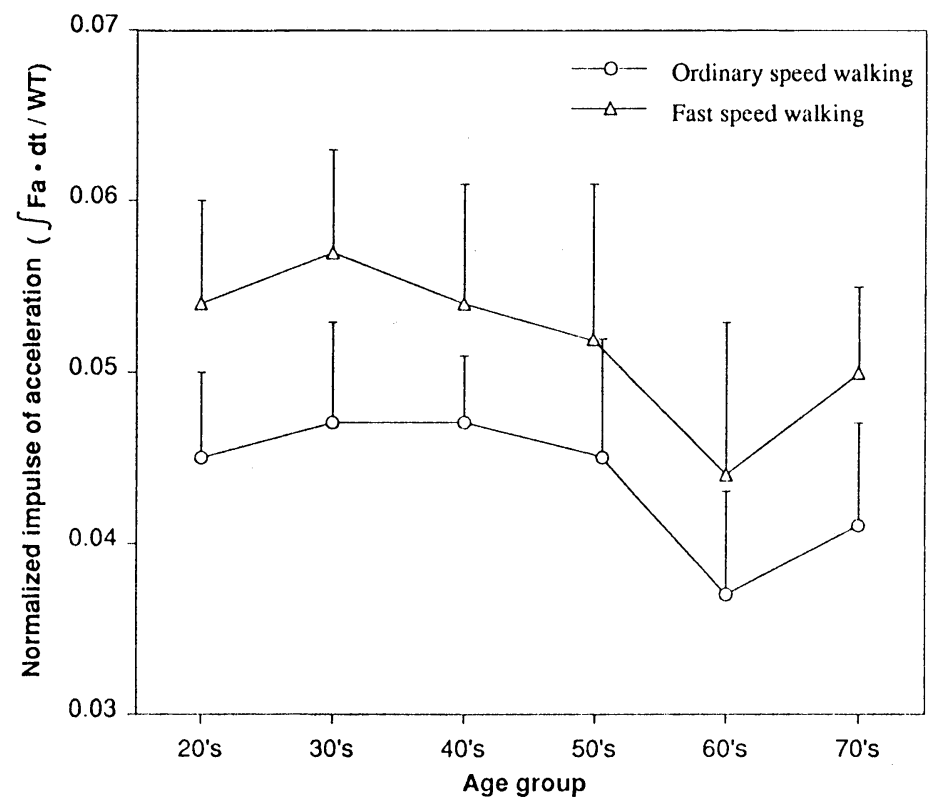

Fig. 5. The mean normalized impulse of acceleration in each age group. Vertical bars indicate $+1 \mathrm{SD}$. 

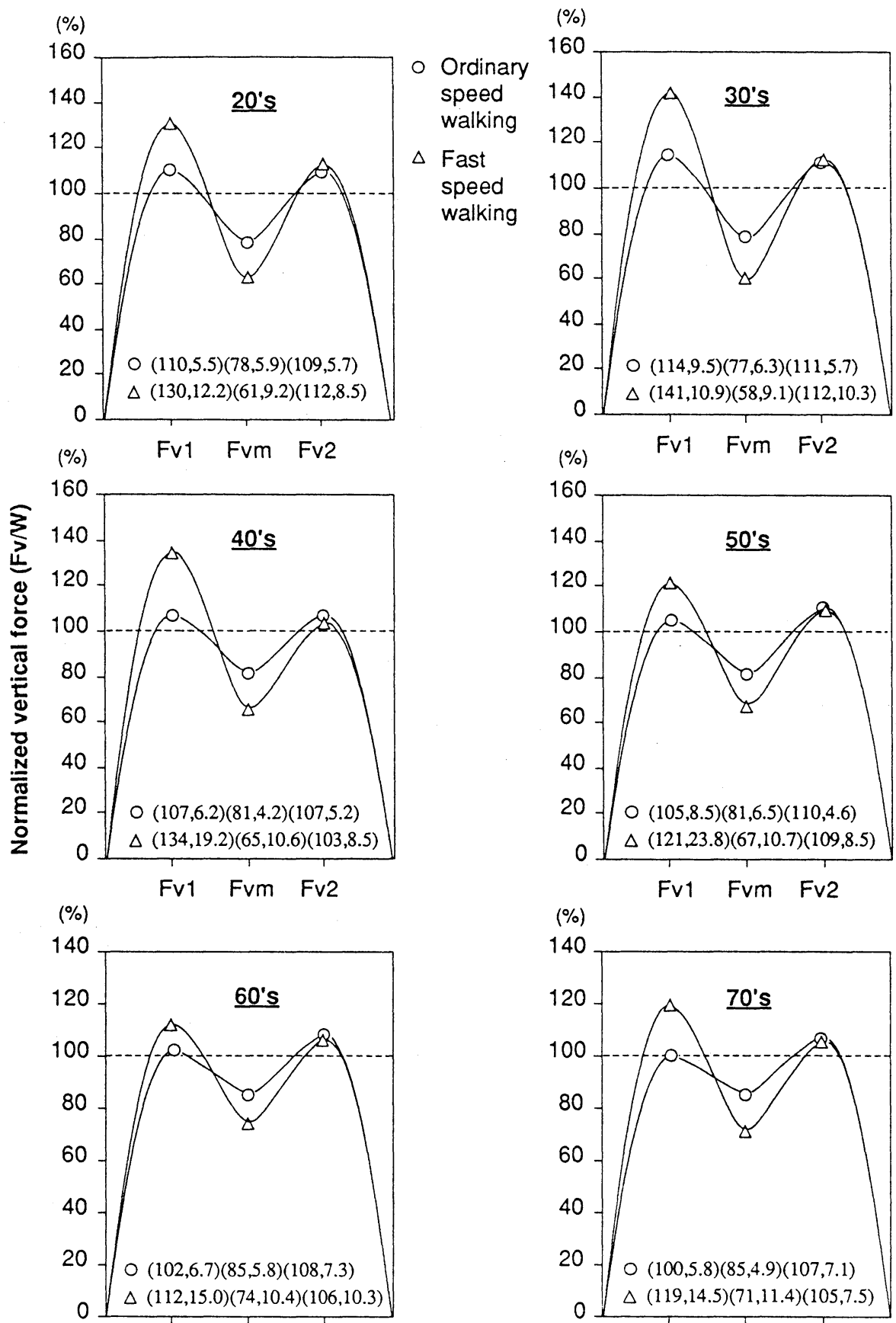

Fv1 Fvm Fv2

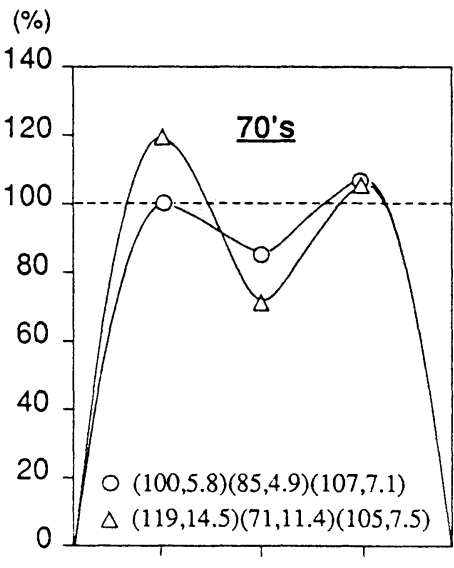

Fv1 Fvm Fv2

Fv1 Fvm Fv2

Fig. 6. Schematic patterns of the normalized vertical force $(\mathrm{Fv} / \mathrm{W})$ in each age group. The numbers in parentheses show, from left to right, the mean value and the standard deviation for Fv1/W, Fvm/W, and Fv2/W, respectively. 
ordinary and fast speed walking in each age group. The step length also decreased according to the age, with a stair pattern at $60 \mathrm{~s}$.

Figs. 4 and 5 show the age-related change of the brake and acceleration impulses, respectively, during the ordinary and fast speed walking. For the fast speed walking, both impulses show a pronounced decrease at $60 \mathrm{~s}$. Those on $70 \mathrm{~s}$ were a little higher than those in $60 \mathrm{~s}$, but it depended on the subjects in their $70 \mathrm{~s}$, who were the members of a gate-ball sport club.

The normalized vertical forces during the ordinary and fast speed walking in each age group are shown in Fig. 6, together with the means for the peak values. In all age groups, the 1st peak forces (Fv1/W) are enhanced during the fast speed walking than during the ordinary speed walking, while the minimum force (Fvm/W) decreased during the fast speed walking from the ordinary speed walking levels. In contrast, the 2nd peak forces (Fv2/W) during the fast speed walking are almost identical with those during the ordinary speed walking in all age groups. Thus, the peaks of the vertical forces even in $60 \mathrm{~s}$ and 70s seemed to be still sharp during the fast speed walking, as compared with those during the ordinary speed walking which were more dull.

The ratios of walking speed, step length, and brake as well as acceleration impulse during the fast speed walking against those during the ordinary speed walking are listed in Table 3 . The mean ratio of the walking speed ranged from 1.40 in 30 s to 1.50 in 40 s, including those in 20 s and $50 \mathrm{~s}$. The mean ratios for $60 \mathrm{~s}$ and 70 s were 1.44 and 1.47 , respectively, which fell within the above range. This appears to indicate that old men in their 60 s and 70 s hastened the walking speeds from ordinary to fast speed in almost the same ratios with those in the younger.

The mean ratios of the step length, from $20 \mathrm{~s}$ to $50 \mathrm{~s}$, were from 1.18 to 1.21 , while those in $60 \mathrm{~s}$ and 70 s were 1.17 and 1.13 , respectively. There was a significant difference in the ratio between 50 s and 70 s by the $t$-test $(p<0.05)$. This means that the old men in their 70s could not increase their step lengths during the fast speed walking as much as the younger.

The mean ratios of the brake impulse from 20 s to 50 s were from 1.43 to 1.49 , while those in $60 \mathrm{~s}$ and $70 \mathrm{~s}$ were 1.17 and 1.27 , respectively. There was a significant difference in the ratio between $50 \mathrm{~s}$ and $60 \mathrm{~s}$ by the t-test $(\mathrm{p}<0.01)$. Absolute values of the brake impulse during the fast speed walking also decreased drastically at one's 60s (Fig. 4). Therefore, it may be concluded that the brake impulse during the fast speed walking begins to decrease at one's $60 \mathrm{~s}$.

The mean ratio of the acceleration impulse from 20 s to 50 s were from 1.15 to 1.24 , while those in $60 \mathrm{~s}$ and $70 \mathrm{~s}$ were 1.21 and 1.23, respectively, which fell within the range from $20 \mathrm{~s}$ to 50s. Unlike the brake impulse, the accelera-

Table 3. Ratios of the measurement items during the fast speed walking against those during the ordinary speed walking in each age group

\begin{tabular}{ccccccccc}
\hline \multirow{2}{*}{$\begin{array}{c}\text { Age } \\
\text { group }\end{array}$} & \multicolumn{2}{c}{$\begin{array}{c}\text { Walking } \\
\text { Mean }\end{array}$} & S.D. & \multicolumn{2}{c}{ Step length } & \multicolumn{2}{c}{ Brake impulse } & \multicolumn{2}{c}{ Accel. impulse } \\
Mean & S.D. & Mean & S.D. & Mean & S.D. \\
\hline $70 \mathrm{~s}$ & 1.47 & 0.22 & 1.13 & 0.10 & 1.27 & 0.28 & 1.23 & 0.10 \\
$60 \mathrm{~s}$ & 1.44 & 0.14 & 1.17 & 0.07 & 1.17 & 0.24 & 1.21 & 0.12 \\
$50 \mathrm{~s}$ & 1.42 & 0.11 & 1.20 & 0.08 & 1.49 & 0.21 & 1.15 & 0.12 \\
$40 \mathrm{~s}$ & 1.50 & 0.14 & 1.18 & 0.08 & 1.44 & 0.44 & 1.16 & 0.10 \\
$30 \mathrm{~s}$ & 1.40 & 0.15 & 1.19 & 0.07 & 1.48 & 0.30 & 1.24 & 0.18 \\
$20 \mathrm{~s}$ & 1.41 & 0.11 & 1.21 & 0.08 & 1.43 & 0.29 & 1.20 & 0.07 \\
\hline
\end{tabular}


Table 4. Correlation coefficients between the measurement items during the fast speed walking

\begin{tabular}{|c|c|c|c|c|c|c|c|c|c|c|c|c|}
\hline & 1 & 2 & 3 & 4 & 5 & 6 & 7 & 8 & 9 & 10 & 11 & 12 \\
\hline 1 Age & 1.00 & & & & & & & & & & & \\
\hline 2 Step length & $-0.64^{* *}$ & 1.00 & & & & & & & & & & \\
\hline 3 Grip strength & $-0.63^{* *}$ & $0.50^{* *}$ & 1.00 & & & & & & & & & \\
\hline 4 Walking speed & $-0.84^{* *}$ & $0.81^{* *}$ & $0.59^{* *}$ & 1.00 & & & & & & & & \\
\hline 5 Fto/W & 0.23 & -0.10 & -0.20 & -0.19 & 1.00 & & & & & & & \\
\hline $6 \int \mathrm{Fto} \cdot \mathrm{dt} / \mathrm{WT}$ & 0.08 & 0.02 & -0.14 & -0.05 & $0.70^{* *}$ & 1.00 & & & & & & \\
\hline $7 \int \mathrm{Fb} \cdot \mathrm{dt} / \mathrm{WT}$ & $-0.62^{* *}$ & $0.71^{* *}$ & $0.38^{* *}$ & $0.73^{* *}$ & -0.17 & 0.00 & 1.00 & & & & & \\
\hline $8 \mathrm{~s} \mathrm{Fa \cdot dt/WT}$ & $-0.33^{* *}$ & $0.43^{* *}$ & 0.15 & $0.48^{* *}$ & -0.05 & 0.11 & $0.50^{* *}$ & 1.00 & & & & \\
\hline $9 \mathrm{Fvl} / \mathrm{W}$ & $-0.41^{* *}$ & $0.44^{* *}$ & 0.11 & $0.57^{* *}$ & $-0.25^{* *}$ & 0.00 & $0.67^{* *}$ & $0.51^{* *}$ & 1.00 & & & \\
\hline $10 \mathrm{Fvm} / \mathrm{W}$ & $0.44^{* *}$ & $-0.51^{* *}$ & -0.23 & $-0.64^{* *}$ & 0.04 & -0.06 & $-0.67^{* *}$ & $-0.65^{* *}$ & $-0.71^{* *}$ & 1.00 & & \\
\hline $11 \mathrm{Fv} 2 / \mathrm{W}$ & $-0.27^{*}$ & 0.19 & 0.14 & $0.28^{*}$ & 0.16 & 0.00 & $0.26^{*}$ & $0.39^{* *}$ & 0.06 & $-0.45^{* *}$ & 1.00 & \\
\hline $12 \mathrm{~S} F \cdot \cdot d t / W T$ & -0.18 & $0.25^{*}$ & -0.03 & $0.27^{*}$ & -0.17 & 0.01 & $0.51^{* *}$ & $0.38^{* *}$ & $0.50^{* *}$ & $0.32^{* *}$ & $0.36^{* *}$ & 1.00 \\
\hline
\end{tabular}

**: significant at the $1 \%$ level, *: significant at the $5 \%$ level

tion impulse in 60 s and 70 s increased during the fast speed walking with almost the same ratio as those in the younger.

The linear correlation coefficients between all pairs of items for the whole subjects and their significance levels are listed in Table 4. The results are almost identical with our previous ones for the ordinary speed walking (YAMADA et al., 1988). Thus, the fundamental relationships between the items appear to be conserved even if the walking speed is hastened.

The results of PCA, for each age group as well as for the whole subjects are listed in Table 5 .

For the fast speed walking in the age groups from $20 \mathrm{~s}$ to $50 \mathrm{~s}$, the 1st component (PC1) is mainly characterized by the brake impulse, walking speed, step length, and Fvm, the 2nd one (PC2) by the outward transverse impulse, and the 3rd one (PC3) by the vertical impulse. Thus, each PC is characterized by each impulse of $\mathrm{Fb}, \mathrm{Ft}$, and $\mathrm{Fv}$. For $60 \mathrm{~s}$ and 70 s, however, the constitution of each $\mathrm{PC}$ was different from those in the age groups from $20 \mathrm{~s}$ to $50 \mathrm{~s}$, and that in 60 s was further different from that in 70 s. These results suggest that the contents of the fast speed walking begin to change at one's 60s.

YAMADA et al. (1988) applied the PCA to the ordinary speed walking using the same items as in the present study, and reported that the constitutions of the principal components were almost identical from 20 s to 40 s. That is, PC1 was mainly characterized by the brake impulse (though the acceleration impulse was included in 20 s and 30 s), PC2 by the outward transverse impulse, PC 3 by the vertical impulse, and they were different according to age groups from 50 s to 70s. Based on these findings, they concluded that the contents of the ordinary speed walking begin to change at one's 50 s.

Comparing the present results with those in YAMADA et al. (1988), it may be concluded that the contents of the fast speed walking from 20 s to 50s were almost identical with those of the ordinary speed walking. In contrast, the age period was different at which the contents of walking began to change; they began to change at one's 60 s in the fast speed walking and at ones $50 \mathrm{~s}$ in the ordinary speed walking. We should, however, notice here that the data used in our study were not longitudinal according to the age but cross-sectional.

As for the whole subjects, the PC1 is mainly characterized by the age, walking speed, and step length, showing that the contents is identical with 
Table 5. Measurement items constituting the principal components for each age group and for whole subjects

\begin{tabular}{|c|c|c|c|}
\hline Age group & PC 1 & PC 2 & PC 3 \\
\hline $70 \mathrm{~s}$ & $\begin{array}{l}\text { Fvm/W }(0.735) \\
\text { speed }(-0.724) \\
\text { step length }(-0.333) \\
(\text { A.C. }=39.3 \%)\end{array}$ & $\begin{array}{l}\int \mathrm{Fa} \cdot \mathrm{dt} / \mathrm{WT}(0.168) \\
\int \mathrm{Fto} \cdot \mathrm{dt} / \mathrm{WT}(-0.227) \\
\text { grip strength }(-0.948) \\
(\text { A.C. }=57.1 \%)\end{array}$ & $\begin{array}{l}\int \mathrm{Ft} \cdot \mathrm{dt} / \mathrm{WT}(-0.908) \\
\text { Fvm/WT }(0.332) \\
\text { speed }(-0.220) \\
\text { (A.C. }=67.8 \%)\end{array}$ \\
\hline $60 \mathrm{~s}$ & $\begin{array}{l}\int \text { Fto } \cdot d t / W T(-0.435) \\
\text { Fvm/W }(0.923) \\
\text { speed }(-0.838) \\
\text { (A.C. }=31.1 \%)\end{array}$ & $\begin{array}{l}\int \mathrm{Fb} \cdot \mathrm{dt} / \mathrm{WT}(0.098) \\
\text { step length }(-0.673) \\
\text { speed }(-0.298) \\
(\text { A.C. }=55.4 \%)\end{array}$ & $\begin{array}{l}\int \text { Fto } \cdot d t / W T(-0.925) \\
\text { step length }(0.308) \\
(\text { A.C. }=70.9 \%)\end{array}$ \\
\hline $50 \mathrm{~s}$ & $\begin{array}{l}\int \mathrm{Fb} \cdot \mathrm{dt} / \mathrm{WT}(-0.600) \\
\text { Fvm/W }(0.228) \\
\text { step length }(-0.888) \\
\text { speed }(-0.728) \\
(\text { A.C. }=32.8 \%)\end{array}$ & $\begin{array}{l}\text { Fvm/W }(0.222) \\
\int \text { Fto } \cdot d t / W T(-0.487) \\
(\text { A.C. }=55.6 \%)\end{array}$ & $\begin{array}{l}\int \mathrm{Fv} \cdot \mathrm{dt} / \mathrm{WT}(-0.966) \\
\int \mathrm{Fb} \cdot \mathrm{dt} / \mathrm{WT}(-0.536) \\
\text { grip strength }(0.217) \\
(\text { A.C. }=72.6 \%)\end{array}$ \\
\hline $40 \mathrm{~s}$ & $\begin{array}{l}\int \mathrm{Fb} \cdot \mathrm{dt} / \mathrm{WT}(-0.730) \\
\mathrm{Fvm} / \mathrm{W}(0.867) \\
\text { speed }(-0.885) \\
(\text { A.C. }=45.2 \%)\end{array}$ & $\begin{array}{l}\int \text { Fto } \cdot d t / W T(-0.807) \\
\text { grip strength }(0.160) \\
(\text { A.C. }=63.7 \%)\end{array}$ & $\begin{array}{l}\int \mathrm{Fv} \cdot \mathrm{dt} / \mathrm{WT}(0.121) \\
\int \mathrm{Fb} \cdot \mathrm{dt} / \mathrm{WT}(-0.246) \\
\text { step length }(-0.387) \\
(\text { A.C. }=75.4 \%)\end{array}$ \\
\hline $30 \mathrm{~s}$ & $\begin{array}{l}\int \mathrm{Fv} \cdot \mathrm{dt} / \mathrm{WT}(0.151) \\
\int \mathrm{Fb} \cdot \mathrm{dt} / \mathrm{WT}(-0.056) \\
\text { step length }(-0.428) \\
(\text { A.C. }=31.4 \%)\end{array}$ & $\begin{array}{l}\int \text { Fto } \cdot d t / W T(-0.396) \\
\text { speed }(0.261) \\
(\text { A.C. }=50.4 \%)\end{array}$ & $\begin{array}{l}\int F v \cdot d t / W T(-0.451) \\
\int F a \cdot d t / W T(-0.267) \\
\text { step length }(0.146) \\
(A . C .=65.9 \%)\end{array}$ \\
\hline $20 \mathrm{~s}$ & $\begin{array}{l}\int \mathrm{Fb} \cdot \mathrm{dt} / \mathrm{WT}(-0.860) \\
\text { Fvm/W }(0.774) \\
\text { speed }(-0.613) \\
\text { (A.C. }=34.0 \%)\end{array}$ & $\begin{array}{l}\int \text { Fto } \cdot d t / W T(-0.955) \\
\text { grip strength }(0.426) \\
(\text { A.C. }=56.2 \%)\end{array}$ & $\begin{array}{l}\int F v \cdot d t / W T(0.174) \\
\int F b \cdot d t / W T(-0.113) \\
\text { speed }(0.329) \\
(\text { A.C. }=71.6 \%)\end{array}$ \\
\hline $\begin{array}{l}\text { Whole } \\
\text { subjects }\end{array}$ & $\begin{array}{l}\text { age }(0.344) \\
\text { Fvm/W }(0.267) \\
\text { speed }(-0.561) \\
\text { step length }(-0.868) \\
\int \mathrm{Fb} \cdot \mathrm{dt} / \mathrm{WT}(-0.597) \\
(\text { A.C. }=43.3 \%)\end{array}$ & $\begin{array}{l}\text { grip strength }(0.106) \\
\int \text { Fto } d t / W T(-0.949)\end{array}$ & $\begin{array}{l}\text { speed }(0.389) \\
\int . F b \cdot d t / W T(0.533) \\
\int \text { Fa・dt/WT }(0.331) \\
\text { Fvm/W }(-0.817) \\
(\text { A.C. }=71.0 \%)\end{array}$ \\
\hline
\end{tabular}

A.C.; accumulated contribution coefficient.

Numbers in parentheses mean eigen values.

that of the ordinary speed walking (YAMADA et al., 1988).

抄録

床反力值からみた高齢者の速歩きの特徴

真家和生・山田忠利・近藤四郎・田中秀幸 
た高齢者の速歩きの特徴を, 通常速度での歩行と比較 しながら検討した，その結果，(1) 歩行速度，歩幅，制 動及び推進の力積は，いずれす60歳台から急速に低下 する, (2) 60歳台・70歳台では速歩きの際, より若い 世代と同様の比率で通常速度歩行時よりも速度を高め ている，(3) 70歳台では, 通常速度歩行と比較した歩 幅の増大率がより若い世代よりも小さい，(4) 通常速 度歩行と比較した前後方向力積の増大率は, 制動力積 では60歳台から弱まるが，推進力積では年代差がない ことがわかった．主成分分析から，(5) 速歩きでは 20 歳台から50歳台まではほぼ同様の主成分からなってお り, 60歳台から歩行の様相が変化することが示唆され た。

\section{References}

ITO, H., H. NAGASAKI, H. MARUYAMA, K. HASHIZUME and R. NAKAMURA, 1989: Age-related changes of the walking cycle during fastest walking in healthy male subjects. Jpn. J. Geriat., 26: 347-352. (In Japanese with English summary)

KIMURA, T., 1985: Bipedal and quadrupedal walking of primates: comparative dynamics. In: KONDO, S. (ed.) Primate Morphology, Locomotor Analyses and Human Bipedalism. Univ. of Tokyo Press, Tokyo, pp. 84-104.

MURRAY, M.P., A.B. DROUGHT and R.C. KORY, 1964: Walking patterns of normal men. J. Bone and Joint Serg., 46-A: 335-360.

MURRAY, M.P. and B.H. ClARKSON, 1966a: The vertical pathways of the foot during level walking: I. Range of variability in normal men. J. Amer. Phys. Therapy Assoc., 46: 585-589.

MURRAY, M.P., R.C. KORY, B.H. ClARKSON and S.B. SEPIC, 1966b: A comparison of free and fast speed walking patterns of normal men. Amer. J. Phys. Med., 45: 8-24.

MURRAY, M.P., S.B. SEPIC and E.J. BARNARD, 1967: Patterns of sagittal rotation of the upper limbs in walking. J. Amer. Phys. Therapy Assoc., 47: 272-284.

MURRAY, M.P., R.C. KORY and B.H. CLARKSON, 1969: Walking patterns in healthy old men. J. Geront., 24: 169-178.

YAMADA, T., K. MAIE and S. KONDO, 1988: The characteristics of walking in old men analysed from the ground reaction force. J. Anthrop. Soc. Nippon, 96: 7-15.

\section{真 家 和 生 大妻女子大学人間生活科学研究所 \\ ₹103 東京都千代田区三番町 12}

Kazuo MAIE Institute of Human Living Sciences

Otsuma Women's University

12 Sanbancho, Chiyoda-ku, Tokyo 102, Japan 